\title{
Muscle wasting after prolonged hypoglycaemic coma: case report with electrophysiological data
}

\author{
M. J. G. HARRISON
}

From the Department of Neurological Studies, the Middlesex Hospital, London

SYNOPSIS A case of distal muscle wasting associated with hypoglycaemia is described. Motor and sensory conduction studies are reported that provide little evidence of a hypoglycaemic peripheral neuropathy. Damage to anterior horn cells or motor roots appears to be a more likely explanation for the amyotrophy. Recovery occurred clinically with evidence of reinnervation by axonal collateral sprouting.

Distal limb muscle wasting, particularly in the hands, has been described after profound hypoglycaemia due to hyperinsulinism (Silfverskiold, 1946; Mulder et al., 1956). As some cases have shown a glove and stocking sensory loss and loss of ankle jerks, it has been argued that the clinical picture is due to a peripheral neuropathy. Electrophysiological support for this was found in a single case studied by Lambert et al. (1960). During recovery, a population of fibres in an ulnar nerve was shown to have a high threshold to electrical stimulation and slow conduction velocity. Few cases have been studied electrophysiologically, however.

Other evidence suggests that a spinal cord lesion may be responsible for the amyotrophy in the hands. A patient studied pathologically by Tom and Richardson (1951) showed evidence of neuronophagia in the ventral horns in the cervical enlargement, and peripheral nerve changes were considered secondary. Another case that came to necropsy showed similar changes (Moersch and Kernohan, 1938), and experimental hypoglycaemia was found to produce ventral horn changes in the spinal cord of the cat (Winkelman and Moore, 1940). A recent patient studied electrophysiologically provides further information on this controversy.

\section{CASE REPORT}

R.C., a 32 year old housewife, was admitted to the Middlesex Hospital on 21 July 1973 under the care of Mr R. D. Illingworth. She had been transferred from an outlying hospital as a possible tumour suspect with a six weeks' history of brief episodes of altered awareness and abnormal behaviour. In these episodes she became aggressive or had a vacant stare and said little. In one attack there was marked lip smacking and after another her conversation remained inappropriate. Though these attacks usually lasted from 30 to 45 minutes, on the day of her admission she had slept most of the day and at bed time had proved unrousable.

It was later learnt that her symptoms followed severe dieting after a rapid gain in weight of $12.7 \mathrm{~kg}$.

On examination on arrival in the Middlesex Hospital she was noted to be orientated but in a dreamy state. She had a mild right hemiparesis. On the following day, she had a probable grand mal fit and became comatose, responding only to painful stimulation.

Blood sugar estimations varied from 2.33 to 6.11 $\mathrm{mmol} / \mathrm{l}$. A series of fasting levels with matched plasma insulin levels revealed that for low normal fasting blood sugars she showed pathologically high insulin levels-for example, $71 \mathrm{mU} / 1$ at a blood sugar of $3.0 \mathrm{mmol} / \mathrm{l}$.

The patient remained stuporose despite the maintenance of normal blood sugar levels. On 13 August 1973 a histologically confirmed insulinoma was removed together with the tail of the pancreas (Prof. L. Le Quesne). 
By 30 August she had begun to respond to verbal command but remained mute. Speech then slowly returned. In the weeks after surgery, wasting of the small muscles of the hands became obvious and when she was mobilized it was clear that she had developed a bilateral flaccid foot drop.

When examined in detail on 28 September 1973 she showed residual cognitive defect, a euphoric affect, and slow tongue movements with a monotonous voice. There was a slight cogwheel rigidity at the right wrist. Both hands showed severe wasting of intrinsic muscles, groups supplied by median and ulnar nerves being equally affected (Fig. 1). There was no weakness of shoulder muscles but there was weakness of the triceps bilaterally and severe distal weakness affected both flexor and extensor muscles. She was unable to abduct her fingers against resistance.
In the lower limbs, wasting was difficult to assess because of oedema. There was diffuse weakness involving extension and flexion of hip and knee. There was a severe bilateral foot drop with associated weakness of plantar flexion. Eversion and inversion of the feet were only just possible against resistance. Dorsiflexion of the toes was impossible. The tendon jerks were all pathologically brisk except for the ankle jerks which were depressed. The plantar responses were both extensor. There were no sensory abnormalities. She was unable to rise from a chair or walk without assistance.

At follow-up 18 months later, the patient was well, looking after a family, and fully ambulant. She was able to do all housework and went to dances. She showed some memory defect and a euphoric affect. She had a mild residual spastic dysarthria and
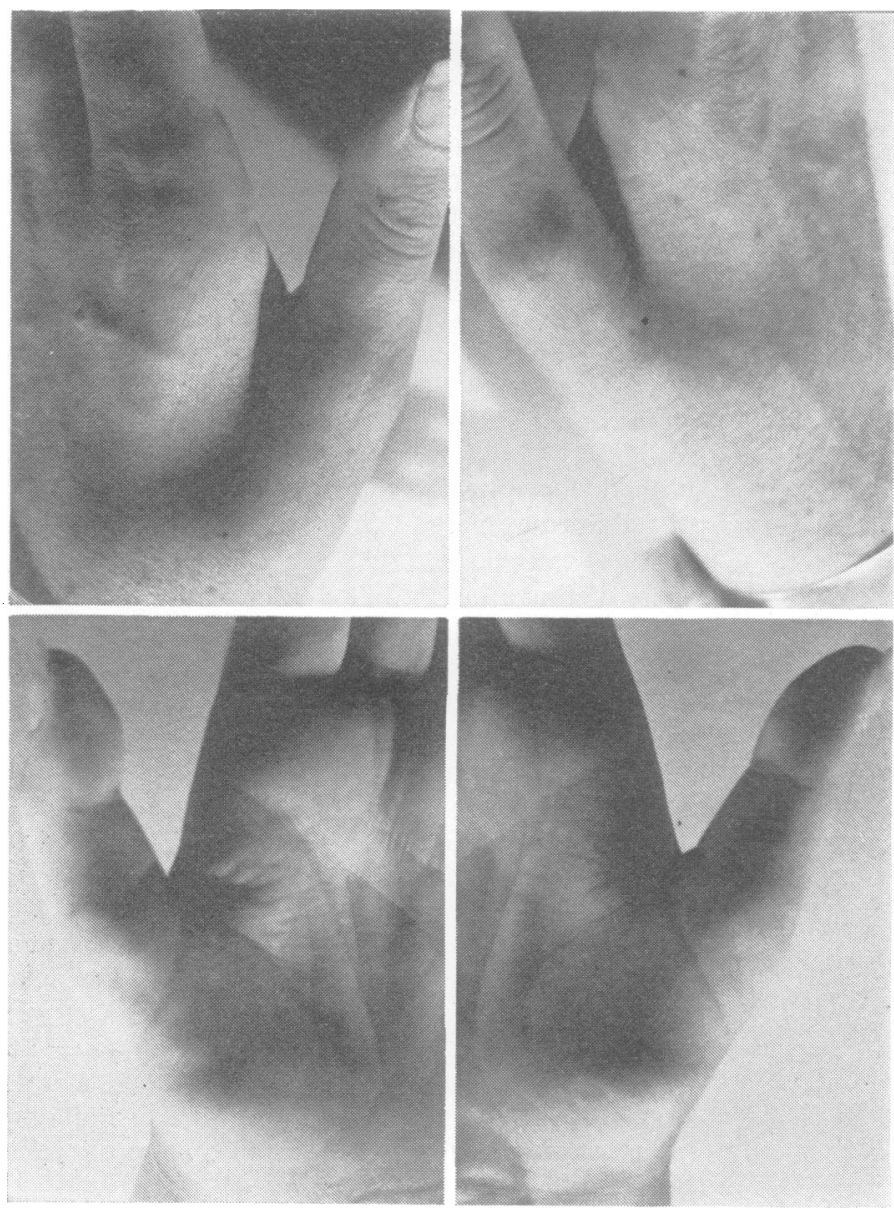

FIG. 1 Appearance of small hand muscles at first examination, one month after regaining consciousness. 
minimal cerebellar deficit in the lower limbs. Her gait was minimally ataxic.

Re-examination of limb muscles revealed residual wasting of ulnar innervated muscles particularly in the right hand. There was no longer evidence of wasting of the thenar eminence on either side (Fig. 2). There was no weakness except of the intrinsic hand muscles supplied by the ulnar nerve (MRC $4+$ ), just detectable weakness of dorsiflexion of the right foot and of the toes of both feet.

The tendon reflexes were all brisk except for the ankle jerks which were normal. The plantar reflexes were flexor. There was no sensory loss to any modality.

ELECTROMYOGRAPHY The studies at the first examination provided evidence of denervation of small hand muscles and of distal muscles in the leg. The nerve conduction studies showed no evidence of a generalized neuropathy, however. The reduced right ulnar nerve motor conduction velocity with reduced ulnar nerve sensory action potential suggested the presence of a superadded ulnar nerve lesion. The amplitude of the lateral popliteal nerve evoked action potential was also small but as the foot was oedematous supramaximal stimulation may not have been achieved. At follow-up there was evidence of reinnervation with near normal or normal EMG interference patterns and motor unit action potentials of large amplitude (over $5 \mathrm{mV}$ ) (Table 1). Motor nerve conduction velocity had increased slightly in some nerves (Table 2). The explanation for this change is not entirely clear. A temperature effect may well have been responsible. Some of the measure-

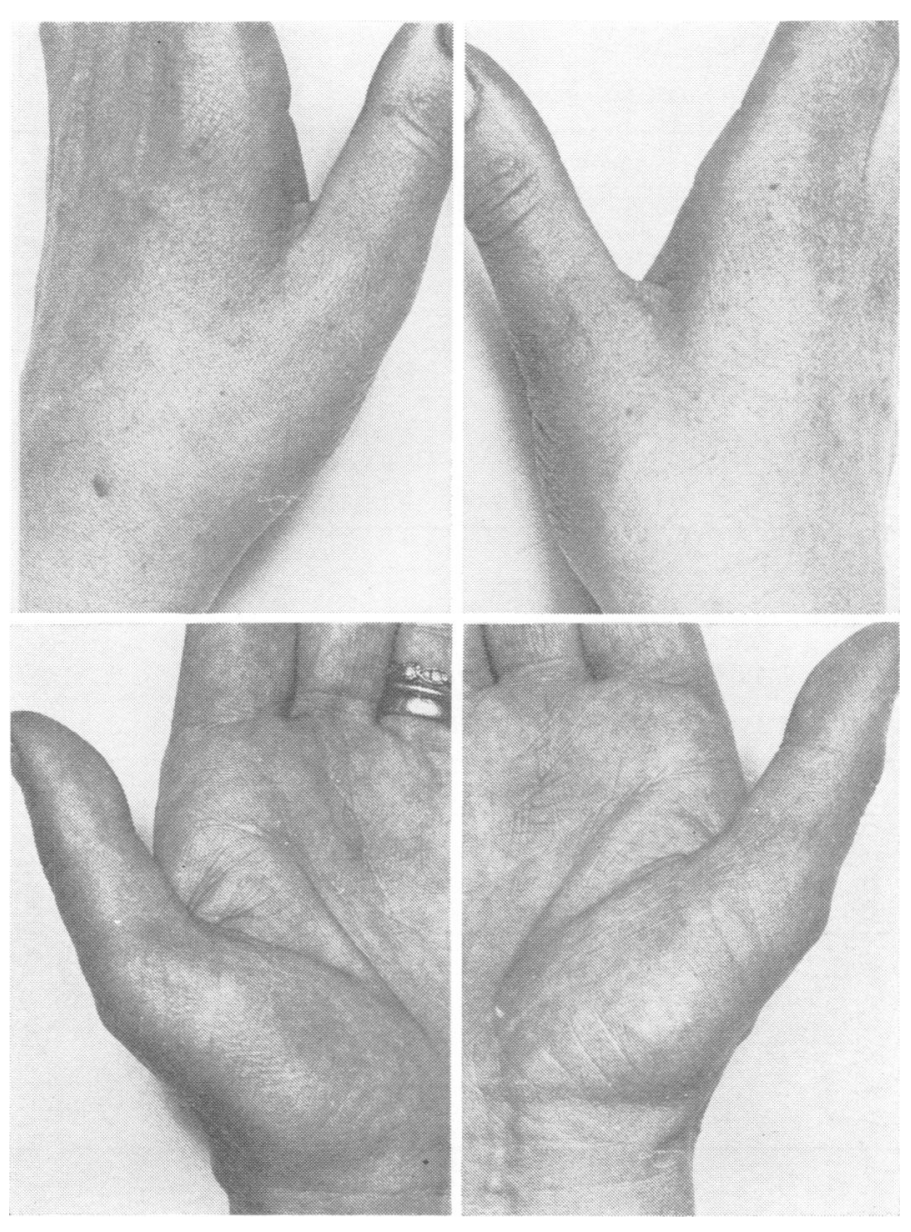

FIG. 2 Appearance of small hand muscles at follow-up examination 18 months later. 
TABLE 1

EMG STUDIES

\begin{tabular}{|c|c|c|c|c|c|c|}
\hline & R. $A P B$ & R. 1st DIO & L. $A P B$ & L. 1st DIO & R. Tib. ant. & $\begin{array}{l}\text { R. abd hall. } \\
\text { brev. }\end{array}$ \\
\hline \multicolumn{7}{|l|}{$\begin{array}{l}\text { First } \\
\text { examination } \\
\text { Sept. '73 }\end{array}$} \\
\hline \multirow{2}{*}{$\begin{array}{l}\text { S. fib. } \\
\text { Interference } \\
\quad \text { pattern }\end{array}$} & + & + & - & - & + & - \\
\hline & $\begin{array}{l}\text { Severely } \\
\text { reduced }\end{array}$ & $\begin{array}{l}\text { Severely } \\
\text { reduced }\end{array}$ & Reduced & Reduced & 1 unit & Few units \\
\hline Amplitude & Normal & Normal & Normal & Normal & Normal & Normal \\
\hline \multicolumn{7}{|l|}{$\begin{array}{l}\text { Second } \\
\text { examination } \\
\text { April '75 }\end{array}$} \\
\hline $\begin{array}{l}\text { S. fib. } \\
\text { Interference }\end{array}$ & - & - & - & - & - & - \\
\hline pattern & Full & $\begin{array}{l}\text { Slightly } \\
\text { reduced }\end{array}$ & Full & Full & $\begin{array}{l}\text { Mod. } \\
\text { reduced }\end{array}$ & $\begin{array}{l}\text { Slightly } \\
\text { reduced }\end{array}$ \\
\hline Amplitude & $8-10 \mathrm{mV}$ & Normal & $5 \mathrm{mV}$ & Normal & $9-10 \mathrm{mV}$ & Normal \\
\hline
\end{tabular}

TABLE 2

MOTOR NERVE CONDUCTION MEASUREMENTS

\begin{tabular}{|c|c|c|c|c|c|c|c|c|c|c|}
\hline & \multicolumn{10}{|c|}{ Nerve } \\
\hline & \multicolumn{2}{|c|}{ R. median } & \multicolumn{2}{|c|}{$R . u l n a r$} & \multicolumn{2}{|c|}{ L. median } & \multicolumn{2}{|c|}{ L. ulnar } & \multicolumn{2}{|c|}{ R. med. pop. } \\
\hline & $\begin{array}{c}D L \\
(m s)\end{array}$ & $\begin{array}{l}M C V \\
(\mathrm{~m} / \mathrm{s})\end{array}$ & $\begin{array}{c}D L \\
(m s)\end{array}$ & $\begin{array}{c}M C V \\
(\mathrm{~m} / \mathrm{s})\end{array}$ & $\begin{array}{c}D L \\
(m s)\end{array}$ & $\begin{array}{l}M C V \\
(\mathrm{~m} / \mathrm{s})\end{array}$ & $\begin{array}{c}D L \\
(m s)\end{array}$ & $\begin{array}{l}M C V \\
(\mathrm{~m} / \mathrm{s})\end{array}$ & $\begin{array}{c}D L \\
(m s)\end{array}$ & $\begin{array}{l}M C V \\
(\mathrm{~m} / \mathrm{s})\end{array}$ \\
\hline $\begin{array}{l}\text { First } \\
\text { examination } \\
\text { Sept. '73 }\end{array}$ & 3.2 & 50 & 3.3 & 44.5 & 3.3 & 50 & 3.6 & 52 & 6.6 & 44 \\
\hline $\begin{array}{l}\text { Second } \\
\text { examination } \\
\text { April' } 75\end{array}$ & 3.8 & 57 & 3.3 & 54.5 & 2.9 & 64 & 2.8 & 60 & 6.8 & 49 \\
\hline Normal values* & $3.8 \pm 0.5$ & $57.2 \pm 4.2$ & & & & & $3.8 \pm 0.5$ & 54.5 上 4.5 & $6.8 \pm 0.9$ & $43.2 \pm 4.9$ \\
\hline
\end{tabular}

* Thomas et al. (1959).

DL: distal motor latency. MCV: motor nerve conduction velocity.

TABLE 3

SENSORY AND NERVE ACTION POTENTIALS

\begin{tabular}{|c|c|c|c|c|c|c|c|c|c|}
\hline & \multicolumn{9}{|c|}{ Nerve } \\
\hline & \multicolumn{2}{|c|}{ R. median } & \multicolumn{2}{|c|}{ R. ulnar } & \multicolumn{2}{|c|}{ L. median } & \multicolumn{2}{|c|}{ L. ulnar } & \multirow{2}{*}{$\frac{R . \text { lat. pop }}{\begin{array}{l}\text { Amp. } \\
(\mu V)\end{array}}$} \\
\hline & $\begin{array}{c}D L \\
(m s)\end{array}$ & $\begin{array}{l}\text { Amp. } \\
(\mu V)\end{array}$ & $\begin{array}{c}D L \\
(m s)\end{array}$ & $\begin{array}{l}A m p \\
(\mu V)\end{array}$ & $\begin{array}{c}D L \\
(m s)\end{array}$ & $\begin{array}{l}\text { Amp. } \\
(\mu V)\end{array}$ & $\begin{array}{c}D L \\
(m s)\end{array}$ & $\begin{array}{l}\text { Amp. } \\
(\mu V)\end{array}$ & \\
\hline $\begin{array}{l}\text { First } \\
\text { examination } \\
\text { Sept.'73 }\end{array}$ & 2.8 & 8 & 2.3 & 6.5 & 2.7 & 11 & 2.3 & 7 & 1 \\
\hline $\begin{array}{l}\text { Second } \\
\text { examination } \\
\text { April '75 }\end{array}$ & 2.6 & 10 & 2.0 & 4 & 2.1 & 9 & 2.1 & 6 & Not done \\
\hline Normal values* & $2.5-4.0$ & $9-45$ & $2.2-3.4$ & $6-28$ & & & & & $1.5-15$ \\
\hline
\end{tabular}


ments on the first occasion were in surviving units of severely denervated muscles, and faster fibres may have been lost selectively. Sensory action potentials were unchanged (Table 3 ). There was still evidence of a lesion of the right ulnar nerve (small sensory action potential).

\section{DISCUSSION}

This patient's distal muscle wasting and weakness is similar to that recorded in previously described cases of hypoglycaemia due to an insulinoma (Mulder et al., 1956; Rosner and Elstad, 1962). Most cases have developed amyotrophy after the insulinoma has produced profound hypoglycaemia that has manifested itself by attacks of confusion or by coma (Lidz et al., 1949). Many have had paraesthesiae but few have had any sensory loss (Mulder et al., 1956). The wasting has been distal and symmetrical and fasciculation has occasionally been reported. Signs of hypoglycaemic damage to cerebral hemispheres and to basal ganglia were present in this case and have been common in previous studies. Exaggerated tendon reflexes have been noted in several cases, though the ankle jerks have usually been depressed.

Electrophysiological studies have been scanty. Denervation has been confirmed in several cases but few conduction studies have been reported. Lambert's patient (Lambert et al., 1960) showed no abnormality of motor nerve conduction when studied acutely. Two years later, when restudied, surface records from abductor digiti minimi revealed evidence of regeneration of nerve fibres in the ulnar nerve after peripheral damage. The vulnerability of the ulnar nerve to trauma raises the possibility that its damage was not directly due to hypoglycaemia, though Lambert did also report that there were similar changes in the median nerve though no details were given. The present patient appears to have had a coincidental ulnar nerve lesion over and above the more diffuse changes. Danta (1969) described two cases with motor conduction velocity measurements. These were normal in both instances at the first examination. Later some reduction in motor conduction velocity was recorded in a lateral popliteal nerve but, in the absence of details about the number of surviving motor units, it is difficult to assess the significance of some of these changes. In the present case, denervation of distal limb muscles was associated with normal motor nerve conduction velocity, and with normal sensory nerve action potentials.

The present data suggest therefore that in this case at least the distal wasting and weakness were not associated with a generalized abnormality of nerve conduction. This situation may be seen with a polyradiculopathy or may be due to cell loss in the anterior horns of the spinal cord as found at necropsy by Tom and Richardson (1951). Recovery was associated with the appearance of large amplitude motor unit potentials in previously denervated muscles suggesting that reinnervation had occurred due to collateral axonal sprouting.

I am grateful to $\mathrm{Mr}$ R. D. Illingworth and $\mathrm{Dr}$ J. D. Nabarro for permission to study this patient, and to Dr R. G. Willison for helpful discussions.

\section{REFERENCES}

Danta, G. (1969). Hypoglycemic peripheral neuropathy. Archives of Neurology (Chic), 21, 121-132.

Gilliatt, R. W., Goodman, M. V., and Willison, R. G. (1961). The recording of lateral popliteal nerve action potentials in man. Journal of Neurology, Neurosurgery, and Psychiatry, 24, 305-318.

Gilliatt, R. W., and Sears, T. A. (1958). Sensory nerve action potentials in patients with peripheral nerve lesions. Journal of Neurology, Neurosurgery, and Psychiatry, 21, 109-118.

Lambert, E. H., Mulder, D. W., and Bastron, J. A. (1960). Regeneration of peripheral nerves with hyperinsulin neuropathy. Neurology (Minneap.), 10, 851-854.

Lidz, T., Miller, J. M., Padget, P., and Stedem, A. F. A. (1949). Muscular atrophy and pseudologia fantastica associated with islet cell adenoma of the pancreas. Archives of Neurology and Psychiatry (Chic.), 62, 304-313.

Moersch, F. P., and Kernohan, J. W. (1938). Hypoglycemia. Neurologic and neuropathologic studies. Archives of Neurology and Psychiatry, 39, 242-257.

Mulder, D. W., Bastron, J. A., and Lambert, E. H. (1956). Hyperinsulin neuropathy. Neurology (Minneap.), 6, 627-635.

Rosner, L., and Elstad, R. (1962). The neuropathy of hypoglycemia. Neurology (Minneap.), 14, 1-6.

Silfverskiold, B. P. (1946). Polyneuritis hypoglycemia. Late peripheral paresis after hypoglycemic attacks in two insuloma patients. Acta Medica Scandinavica, 125, 502-504. 
Thomas, P. K., Sears, T. A., and Gilliatt, R. W. (1959). The range of conduction velocity in normal motor nerve fibres to the small muscles of the hand and foot. Journal of Neurology, Neurosurgery, and Psychiatry, 22, 175-181.

Tom, M. I., and Richardson, J. C. (1951). Hypoglycemia from islet cell tumor of pancreas with amyotrophy and cerebrospinal nerve cell changes. Journal of Neuropathology and Experimental Neurology, 10, 57-66.

Winkelman, N. W., and Moore, M. T. (1940). Neurohistopathologic changes with metrazol and insulin shock therapy. Archives of Neurology and Psychiatry (Chic.), 43, 1108-1137. 